\title{
PENGARUH VARIASI PIGMEN UNTUK LAPISAN DASAR (BASE COAT) PADA PROSES FINISHING TERHADAP SIFAT FISIK KULIT SAPI
}

\section{THE EFFECT OF PIGMENT VARIATION AT THE BASE COAT IN THE FINISHING PROCESS TOWARDS PHYSICAL PROPERTIES OF CALF LEATHER}

\author{
Gresy Griyanitasari*, Emiliana Kasmudjiastuti, dan Bidhari Pidhatika \\ Balai Besar Kulit, Karet, dan Plastik, Yogyakarta, 55166
}

Submitted: 25 November 2016, Accepted: 20 July 2017

\section{INTISARI}

Permintaan kulit yang bermutu semakin meningkat tetapi ketersediaannya semakin menurun. Teknologi pasca penyamakan (finishing) merupakan hal yang dapat dilakukan untuk menutupi kerusakan kulit. Salah satu bahan finishing kulit yang dapat digunakan untuk menutupi cacat kulit adalah pigmen. Penelitian ini bertujuan untuk mengetahui pengaruh penambahan jumlah pigmen pada lapisan dasar terhadap sifat fisik kulit tersamak. Kulit sapi yang sudah disamak ulang diberi perlakuan finishing dengan variasi pigmen 7,$5 ; 10 ; 12,5 ; 15$; dan $17,5 \%$ pada lapisan dasar. Hasil penelitian menunjukkan bahwa pigmen berpengaruh pada penyerapan air selama dua jam dan ketebalan lapisan finishing. Formulasi dengan berbagai variasi pigmen dalam penelitian ini memenuhi standard SNI 0234: 2009 kulit bagian atas alas kaki-kulit boks dan ISO 20879: 2007 footwear performance requirements for footwear-upper dari segi ketahanan gosok cat (kering dan basah), penyerapan air (2 dan 24 jam), dan permeabilitas uap air.

(Kata kunci: Finishing, Kulit sapi, Pigmen, Permeabilitas uap air)

\section{ABSTRACT}

The demand of high quality leather is increasing, but it's availability gradually decrease. Finishing of the tanning process is technology to upgrade the quality of leather. Pigment is one of the materials for finishing leather that can correcting grain. The aim of this research was to determine the best variation of pigment addition as base coat on physical properties of leather. Retanned cow hide was treated using finishing agent for 7,$5 ; 10 ; 12.5 ; 15$; and $17.5 \%$ of pigment as base coat. This study revealed pigment, as one of basecoat material, affected water absorption for two hours and also leather coating thickness. Finishing formulation of various pigment in tanning process of this research met to SNI 0234:2009 requirements and ISO 20879:2007 for footwear performance requirements of footwear-upper for rub fastness (wet and dry), water absorption (2 and 24 hours), and water vapour permeability.

(Keywords: Cow leather, Finishing, Pigment, Water vapour permeability)

\section{Pendahuluan}

Kulit merupakan material yang memiliki keunikan dalam hal kekuatan, ketahanan, keelastisan, kenyamanan, dan kekakuan (stiffness), sehingga kedudukannya masih belum tergantikan bahan lain (Sundar et al., 2006). Akan tetapi, semakin meningkatnya kepedulian masyarakat pada penyembelihan hewan dan langkanya bahan mentah menyebabkan tingginya permintaan akan kulit yang berkualitas baik (Sundar et al., 2006; Olle et al., 2014). Kulit yang baik adalah kulit yang bersih dan tidak memiliki banyak cacat. Kulit tersebut merupakan bahan mentah bagi berbagai sektor industri yang dapat diubah menjadi berbagai barang, seperti sepatu, mebel, dan barang otomotif (Fantová et al., 2015).

\footnotetext{
* Korespondensi (corresponding author):

Telp. +6287839454589

E-mail: gresy-griyanitasari@kemenperin.go.id
} 
Kulit mentah bersifat sangat rentan terhadap parasit dan kesalahan manusia yang dapat mengakibatkan turunnya kualitas kulit (Kahsay et al. 2015). Kerusakan kulit mentah sangat memengaruhi kualitas akhir kulit tersamak. Proses penyamakan, mulai dari perendaman hingga pengeringan, tidak dapat menutupi kerusakan kulit mentah. Cara yang dapat dilakukan untuk mengurangi atau bahkan menutupi kerusakan kulit tersebut adalah dengan pengampelasan atau diperbaiki dengan pigmen yang kemudian dilanjutkan ke proses pasca penyamakan (finishing) (Sundar et al., 2006; Kasmudjiastuti et al., 2016). Selain dapat menyembunyikan kerusakan kulit, finishing juga dapat meningkatkan sifat fisik kulit tersamak (Xu et al., 2013), melindungi dari kotoran, noda, air, tekanan mekanis seperti gosokan, pukulan, dan bengkukan (Yilmaz et al., 2011; Wakaso, 2014), serta menentukan produk akhir (Kasmudjiastuti et al., 2016).

Pada proses finishing kulit, dilakukan dua tahap, yaitu pemberian lapisan dasar (base coat) dan lapisan atas (top coat) (Yilmaz et al., 2011). Pemberian lapisan dasar pada proses finishing merupakan hal yang penting karena sangat memengaruhi sifat fisik kulit (Sundar et al., 2006). Bahan yang digunakan untuk membuat lapisan dasar antara lain terdiri dari pengikat (binder), pigmen (Sundar et al., 2006), wax, plasticizer, bahan pengisi, dan penetrator (Kasmudjiastuti et al., 2016).

Pigmen merupakan salah satu bahan yang dapat digunakan untuk menutupi cacat yang dalam pada kulit (Aravindhan et al., 2008). Fungsi pigmen selain mempunyai kemampuan menutupi cacat juga dapat memberikan warna yang menarik dan mempunyai ketahanan terhadap panas dan absorbsi (Wakaso, 2014). Terdapat beberapa penelitian yang telah dilakukan mengenai pigmen yang digunakan untuk finishing kulit. Salah satunya adalah penelitian yang dilakukan oleh Aravindhan et al. (2008) yang menggunakan pigmen pada proses pra finishing untuk menutupi kerusakan kulit. Hasil penelitian tersebut menyatakan bahwa pigmen yang larut dalam air jika diaplikasikan sesudah proses penyamakan memberikan hasil yang baik dalam hal menutup kerusakan, kedalaman, keseragaman warna, dan peningkatan secara keseluruhan. Akan tetapi, penggunaan pigmen yang kurang tepat dapat menurunkan nilai tambah (Covington, 2009) dan menghilangkan keaslian penampakan serta rasa (feel) kulit (Wakaso, 2014), sehingga perlu diketahui jumlah pigmen yang baik untuk menutupi kerusakan kulit.

Selain jumlah pigmen dan binder, sifat fisik kulit jadi juga ditentukan pada tahap pemberian lapisan atas. Formulasi pemberian lapisan atas dapat menentukan penampakan, pegangan, ketahanan terhadap kelunturan basah dan kering, serta ketahanan terhadap perlakuan panas (Wakaso, 2014). Selain itu, lapisan atas berfungsi untuk meningkatkan ketahanan gosok dan memberikan efek kilap (Sumarni, et al., 2013).

Jumlah pigmen dan binder yang digunakan pada proses finishing beraneka ragam, sehingga kulit yang dihasilkan memiliki kualitas yang tidak sama. Inkonsistensi kualitas tersebut merupakan salah satu masalah pada finishing kulit karena tidak ada ilmu pasti tentang jumlah binder dan pigmen yang diaplikasikan pada berbagai jenis kulit (Wakaso, 2014). Oleh karena itu, terkait jumlah pigmen yang digunakan dan efek pemberian lapisan atas, tujuan penelitian ini mengetahui variasi terbaik penambahan jumlah pigmen pada lapisan dasar.

Pigmen yang digunakan pada proses finishing dapat memengaruhi ketebalan kulit. Beberapa penelitian telah dilakukan untuk mengetahui hubungan ketebalan kulit dengan permeabilitas dan penyerapan uap air (Jankauskaite et al., 2004; Smiechowski, 2014; Kasmudjiastuti et al., 2016). Kulit merupakan bahan yang paling diperhatikan saat pembuatan alas kaki, sehingga terdapat beberapa parameter yang mempunyai pengaruh besar pada mutu kulit, seperti permeabilitas uap air (water vapour permeability) penyerapan uap air (water vapour absorption) kulit (Smiechowski et al., 2014; Wu et al., 2014; Kasmudjiastuti et al., 2016). Kedua faktor tersebut berperan dalam pelepasan keringat si pemakai, terutama saat berkeringat (Wu et al., 2014). Beberapa penelitian telah dilakukan terkait permeabilitas dan penyerapan uap air pada kulit. Salah satu di antaranya adalah penelitian (Jankauskaite et al., 2004) yang melakukan penelitian tentang lapisan poliuretan pada finishing kulit. Hasil penelitian tersebut menyatakan bahwa lapisan poliuretan yang melapisi kulit 
menunjukkan perilaku transmisi uap air yang tidak biasa.

Penelitian Smiechowski et al. (2014) yang mengetahui permeabilitas uap air pada kulit yang digunakan untuk produk berbasis kenyamanan, seperti sepatu. Hasil penelitian tersebut menunjukkan bahwa kulit yang telah diberi perlakuan finishing tersebut memiliki mutu yang baik dengan nilai permeabilitas uap air berada pada kisaran 380 $\mathrm{mg} / 10 \mathrm{~cm}^{2} / 24 \mathrm{~h}$ sampai $4930 \mathrm{mg} / 10 \mathrm{~cm}^{2} / 24 \mathrm{~h}$ dan semakin tinggi ketebalan lapisan finishing semakin rendah nilai permeabilitas uap air.

Penelitian tentang permeabilitas dan penyerapan uap air pada kulit juga telah dilakukan oleh Kasmudjiastuti et al. (2016) yang menyatakan bahwa penambahan binder resin uretan dan motif embossing pada proses finishing dapat memengaruhi mutu kulit. Pada penelitian tersebut penggunaan resin uretan sebanyak 200 bagian dengan berbagai motif emboss menunjukkan nilai permeabilitas uap air yang tertinggi dibandingkan dengan jumlah resin uretan lain. Di samping itu, pada penelitian tersebut dapat diketahui bahwa penggunaan binder resin uretan pada proses finishing dapat meningkatkan nilai penyerapan uap air. Namun penggunaan pigmen dengan berbagai variasi belum banyak data yang dihasilkan, oleh karena itu penelitian ini bertujuan untuk mengaplikasikan pigmen dengan berbagai level konsentrasi terhadap kualitas fisik kulit sapi samak.

\section{Materi dan Metode}

\section{Materi}

Materi yang digunakan pada penelitian ini terdiri atas bahan baku, bahan proses, dan bahan finishing. Bahan baku yang digunakan yaitu kulit sapi wet blue yang diperoleh dari penjual kulit di Yogyakarta, sedangkan bahan proses meliputi Alcem CSAN, Asam Formiat, Yolkanol L5CC, Retingan R7, Tanigan PAK, Chromosal B, Tanigan OS, Natrium Formiat, Novaltan PF, Mimosa, Tanigan PR, Baygenal Brown EDN, Baygenal Brown CBN, Leathernol SPU, Leathernol BML, dan Eurokanol 821.

Bahan finishing meliputi pigmen, resin akrilik, resin uretan, binder protein, wax-filler, penetrator, lak air, pewarna cair, lak pelarut, tiner. Bahan proses dan bahan finishing tersebut diperoleh dari distributor bahan kimia di Yogyakarta.
Alat yang digunakan pada penelitian ini meliputi alat untuk proses penyamakan dan finishing kulit, yaitu drum penyamakan, termometer, kuda-kuda, alat pementang kulit, spray gun, spons, mesin ironing merek Satilux, embossing press merek Mostardini, cawan plastik, dan kertas $\mathrm{pH}$. Alat untuk pengujian meliputi AATC Crockmeter Merek ATLAS model M238AA, Water Vapour Permeability Apparatus merek SATRA seri STM 473, Light Box merek Verivide, cawan petri, botol plastik, Scanning Electron Microscopy merek SNE3200M, dan SG300 substance gauge merek MSA Engineering.

\section{Metode}

Proses penyamakan ulang (retanning). Bahan baku yang digunakan pada penelitian ini adalah enam side kulit sapi wet blue yang masing-masing memiliki luas $\pm 25 \mathrm{ft}^{2}$. Untuk mengontrol mutu, kulit wet blue tersebut disamak ulang dengan formulasi yang tertera pada Tabel 1 . Persentase dihitung berdasarkan berat kulit. Mula-mula dilakukan pembasahan ulang pada kulit wet blue untuk mengembalikan kondisi kulit dengan kadar air yang baik. Selanjutnya, kulit disamak ulang dua kali dengan beberapa bahan penyamak ulang (retanning agent) yang sesuai untuk pembuatan kulit boks. Sebelum fiksasi kulit diberi warna coklat dan diberi minyak (fatliquor) agar memiliki warna dan kelemasan sesuai kulit boks.

Proses finishing. Setelah proses penyamakan ulang, tahapan selanjutnya adalah proses finishing kulit. Finishing terdiri atas pemberian lapisan dasar, emboss, efek, dan lapisan atas. Pada penelitian ini dilakukan variasi penambahan jumlah pigmen pada lapisan dasar yaitu 7,5 ; 10; 12,5; 15; dan 17,5\% (Tabel 2). Embossing dilakukan pada suhu $95^{\circ} \mathrm{C}$, tekanan 200 Bar, dan dalam waktu 20 detik. Formulasi efek dan lapisan atas dapat dilihat pada Tabel 3. Kontrol yang digunakan pada penelitian ini adalah kulit boks yang diperoleh dari salah satu sentra kerajinan kulit, yaitu Magetan, Jawa Timur.

Pengujian. Parameter yang diuji pada hasil penelitian difokuskan pada sifat-sifat kulit yang terkait dengan perlakuan finishing meliputi ketahanan gosok cat tutup kering, ketahanan gosok cat tutup basah, penyerapan air selama 2 jam, penyerapan air selama 24 jam, permeabilitas uap air (water vapour permeability), penyerapan uap air 
(water vapour absorption), ketebalan kulit, dan ketebalan lapisan finishing.

Uji ketahanan gosok cat tutup kering dilakukan sesuai dengan metode ISO 20433: 2012 (en) Leather - Tests for colour fastness
- Colour fastness to crocking (ISO, 2012), yaitu dengan kulit dipotong dengan ukuran 140 × $50 \mathrm{~mm}$ lalu dikondisikan di ruang kondisi setidaknya 24 jam. Selanjutnya spesimen dikencangkan pada papan uji

Tabel 1. Formulasi penyamakan ulang (retanning) kulit sapi wet blue (retanning formulation of wet blue calf leather)

\begin{tabular}{|c|c|c|c|c|}
\hline $\begin{array}{l}\text { Proses } \\
\text { (process) }\end{array}$ & $\%$ & $\begin{array}{c}\text { Bahan } \\
\text { (ingredients) }\end{array}$ & $\begin{array}{c}\text { Lama proses (menit) } \\
\text { (time (minute)) }\end{array}$ & $\begin{array}{l}\text { Keterangan } \\
\text { (information) }\end{array}$ \\
\hline Pembasahan & 200 & Air $\left(40^{\circ} \mathrm{C}\right)$ & & \\
\hline ulang & 0,5 & Alcem CSÁN & & \\
\hline (wetting back) & 0,2 & Asam Formiat & 60 & Buang air, cuci \\
\hline \multirow{7}{*}{$\begin{array}{l}\text { Penyamakan } \\
\text { ulang I } \\
\text { (retanning I) }\end{array}$} & 100 & Air $\left(40^{\circ} \mathrm{C}\right)$ & & \multirow[b]{7}{*}{$\begin{array}{l}\text { Diamkan semalam, } \\
\text { buang air, cuci }\end{array}$} \\
\hline & 0,5 & Yolkanol L5CC & 30 & \\
\hline & 2 & Altan MS & 30 & \\
\hline & 2 & Altan $\mathrm{T}$ & 30 & \\
\hline & 2 & Chromosal B & & \\
\hline & 1 & Tanigan OS & 60 & \\
\hline & 1 & Sodium format & 20 & \\
\hline \multirow{6}{*}{$\begin{array}{c}\text { Penyamakan } \\
\text { ulang II } \\
\text { (retanning II) }\end{array}$} & 150 & Air & & \multirow[b]{6}{*}{ Buang air, cuci } \\
\hline & 1,5 & Tanigan PAK & & \\
\hline & 1,5 & Sodium format & & \\
\hline & 1 & Retingan R7 & 20 & \\
\hline & 0,6 & Soda kue & 30 & \\
\hline & 1,5 & Retingan R7 & 20 & \\
\hline \multirow{21}{*}{$\begin{array}{l}\text { Pewarnaan } \\
\text { (dyeing), } \\
\text { Peminyakan } \\
\text { (fatliquoring) }\end{array}$} & 50 & Air $\left(40^{\circ} \mathrm{C}\right)$ & & \\
\hline & 1 & Yolkanol L5CC & 20 & \\
\hline & 2 & Leukotan 1084 & & \\
\hline & 2 & Levotan AT & 20 & \\
\hline & 3 & Retingan R12 & 20 & \\
\hline & 1,5 & Mimosa & & \\
\hline & 1 & Tanigan OS & & \\
\hline & 1 & Baykanol PFMC & & \\
\hline & 1 & Tanigan PR & 40 & \\
\hline & & Bahan Pewarna: & & \\
\hline & & Baygenol brown & & \\
\hline & 1 & EDN & & \\
\hline & 1,5 & $\begin{array}{l}\text { Baygenol brown } \\
\text { CBN }\end{array}$ & 40 & \\
\hline & 1,5 & Mimosa & 40 & \\
\hline & 1,5 & Leukotan 1084 & 20 & \\
\hline & 2 & Leathernol SPU & & \\
\hline & 2 & Leathernol BML & & \\
\hline & 2 & Eurokanol 821 & 30 & \\
\hline & 100 & Air $\left(60^{\circ} \mathrm{C}\right)$ & 30 & \\
\hline & 1 & Asam Formiat & 20 & \\
\hline & 1 & Asam Formiat & 20 & Buang air, cuci \\
\hline
\end{tabular}

Tabel 2. Formulasi lapisan dasar (base coat) dengan variasi pigmen (base coat formulation with pigment variation)

\begin{tabular}{lccccc}
\hline \hline $\begin{array}{c}\text { Lapisan dasar } \\
\text { (base coat) }\end{array}$ & $\begin{array}{c}\text { Variasi 1 } \\
\text { (variation 1) }\end{array}$ & $\begin{array}{c}\text { Variasi 2 } \\
\text { (variation 2) }\end{array}$ & $\begin{array}{c}\text { Variasi 3 } \\
\text { (variation 3) }\end{array}$ & $\begin{array}{c}\text { Variasi 4 } \\
\text { (variation 4) }\end{array}$ & $\begin{array}{c}\text { Variasi 5 } \\
\text { (variation 5) }\end{array}$ \\
\hline Pigmen (\%) (pigment (\%)) & 7,5 & 10 & 12,5 & 15 & 17,5 \\
Resin akrilik (\%) (acrylic resin (\%)) & 10 & 10 & 10 & 10 & 10 \\
Resin uretan (\%) (urethane resin (\%)) & 20 & 20 & 20 & 20 & 20 \\
Binder protein (\%) (protein binder (\%)) & 5 & 5 & 5 & 5 & 5 \\
Wax - Filler (\%) & 3 & 3 & 3 & 3 & 3 \\
Penetrator (\%) & 2 & 2 & 2 & 2 & 2 \\
Air (\%) (water (\%)) & 52,5 & 50 & 47,5 & 45 & 42,5 \\
\hline & Semprot (spray) 2X \\
& Di-emboss (embossed) \\
\hline
\end{tabular}


Tabel 3. Formulasi efek dan lapisan atas (effect and top coat formulation)

\begin{tabular}{cccc}
\hline \hline Tahapan proses (process) & Bahan (materials) & Jumlah (quantity), gram & Perlakuan (treatment) \\
\hline & Binder protein (protein binder) & 100 & \multirow{2}{*}{ Tip } \\
& Lak air (lacquer water) & 200 & \\
& Pewarna cair (liquid dyes) & 50 & \\
\cline { 2 - 4 } Efek (effect) & Binder protein (protein binder) & 100 & Semprot (spray) \\
& Uretan resin (resin urethane) & 100 & 2 X \\
& Pewarna cair (liquid dyes) & 25 & \multirow{2}{*}{ Semprot (spray) } \\
& Air (water) & 275 & 1 X dan plate \\
\hline \multirow{2}{*}{ Lapisan atas } & Lak pelarut (lacquer solvent) & 250 & 10 \\
Slip agent & Tiner (thinner) & 750 & \\
\hline
\end{tabular}

dan kain yang kering dipasangkan pada Crockmeter. Alat uji Crockmeter digosokkan ke kiri sebanyak 10 kali dan ke kiri sebanyak 10 kali. Terakhir, untuk mengetahui nilai ketahanan gosok cat basah, kulit yang sudah digosok dicocokkan dengan standard Gray Scale for Assesing Change In Colour (Including half-step) dengan nilai antara 1 sampai 5 , nilai 1 berarti mayoritas warna hilang dan nilai 5 berarti tidak ada warna yang hilang. Kain yang digosokkan dicocokkan dengan standard Gray Scale for Assesing Change in Colour (Including halfstep) yang dilihat dalam Light Box merek Verivide. Metode yang sama juga dilakukan untuk uji ketahanan gosok cat basah, tetapi kain yang digunakan sudah dibasahi dengan air destilasi hingga air terserap $20 \pm 5 \%$ terlebih dahulu.

Uji penyerapan air dilakukan dengan metode dalam SNI 06-0997-1989: Cara uji penyerapan air kulit tersamak (BSN, 1989). Kulit yang sudah dipotong dengan bentuk lingkaran berdiameter $7 \mathrm{~cm}$ ditimbang berat awalnya lalu direndam dalam wadah berisi aquades selama 2 jam (untuk penyerapan air selama 2 jam) hingga tercelup sempurna. Selanjutnya ditiriskan selama 10 menit dan ditimbang. Untuk mengetahui penyerapan air selama 24 jam, kulit dimasukkan kembali ke dalam air hingga tercelup dan didiamkan selama 24 jam, ditiriskan selama 10 menit, kemudian ditimbang. Penyerapan air dapat diketahui dengan persamaan 1 (ISO, 2011) berikut:

$$
\text { Penyerapan atr }=\frac{\text { (Borat akhir-Borat awai) }}{\text { Berat ahhw }} \times 100 \%
$$

Selanjutnya uji permeabilitas uap air telah dilakukan sesuai dengan ISO 14268: 2012: Leather - Physical and mechanical tests - Determination of water vapour permeability (ISO, 2012a), yaitu Sampel kulit yang telah dipotong berbentuk lingkaran dengan diameter $3,5 \mathrm{~cm}$ diletakkan di dalam tutup botol yang di dalamnya diisi gel silika lalu ditimbang, kemudian dimasukkan ke Water Vapour Permeability Apparatus selama 8-16 jam. Setelah itu, berat akhir ditimbang dan dihitung mengunakan persamaan 2 (ISO, 2011) berikut:

Permeabilitas uap air $=\frac{\text { (Berat awal-Berat akhin) }}{\pi^{2} \times 16 \mathrm{jom}}$

Selanjutnya, pengujian penyerapan uap air dilakukan sesuai dengan ISO 17229: 2016: Leather - Physical and mechanical test - Determination of water vapour absorption (ISO, 2016). Berdasarkan standard tersebut, sampel kulit yang telah dipotong berbentuk lingkaran dengan diameter $3,5 \mathrm{~cm}$ diletakkan di dalam tutup botol yang didalamnya diisi aquades. Berat awal ditimbang dan didiamkan selama 8 jam. Berat akhir ditimbang dan dihitung menggunakan persamaan 3 (ISO, 2011) berikut:

Penyerapar way apr $=\frac{\text { Berat skhbr-Beratawal }}{\pi^{2}}$

Untuk uji ketebalan lapisan finishing dilakukan dengan mengukur ketebalan lapisan menggunakan Structural Electron Microscopy (SEM), sedangkan ketebalan kulit diukur dengan melihat ketebalan kulit menggunakan SG300 substance gauge. Penelitian ini menggunakan rancangan acak lengkap dengan pengaruh perlakuan dianalisa menggunakan bantuan perangkat SPSS 16.0.

\section{Hasil dan Pembahasan}

\section{Ketahanan gosok cat tutup}

Hasil uji ketahanan gosok cat tutup (kering dan basah) dapat dilihat pada Gambar 1. Gambar tersebut terlihat bahwa semua perlakuan mempunyai nilai ketahanan gosok sama seperti kulit kontrol, yaitu 5, baik untuk ketahanan gosok cat kering maupun basah. Nilai 5 berarti tidak ada warna yang 
hilang, sehingga seluruh persentase pigmen yang digunakan pada proses finishing dapat melekat dengan baik.

Semua sampel dalam penelitian ini memenuhi persyaratan SNI 0234: 2009 kulit bagian atas alas kaki-kulit boks (BSN, 2009), yang mensyaratkan nilai ketahanan gosok cat kering sebesar 5, yang artinya tidak luntur dan ketahanan gosok cat basah sebesar 4/5 yang artinya sedikit luntur. Ketahanan gosok cat yang baik menunjukkan bahwa komposisi binder dan pigmen yang digunakan pada penelitian ini adalah tepat baik, sehingga terbentuk ikatan yang kuat antara keduanya karena binder berfungsi untuk mengikat pigmen dengan kulit (Sundar et al., 2006). Perpaduan binder dan pigmen dapat memberikan daya rekat, kelemasan, dan kelenturan pada kulit. Disamping itu, ketahanan gosok cat juga dapat dipengaruhi oleh jumlah resin yang digunakan, semakin tinggi jumlah resin yang digunakan untuk lapisan atas, maka semakin baik ketahanan gosok cat basah, namun ketahanan gosok cat kering berkurang (Olle et al., 2014). Perpaduan resin dan pigmen dalam penelitian ini dapat menghasilkan ketahanan gosok cat tutup yang baik. Jumlah pigmen yang digunakan pada proses finishing berpengaruh pada daya menutup cacat kulit pada nerf/grain. Pigmen sebanyak 7,$5 ; 10 ; 12,5 ; 15$; dan $17,5 \%$ sebagai lapisan dasar menghasilkan ketahanan gosok cat tutup basah dan kering yang sesuai dengan SNI 0234: 2009 kulit bagian atas alas kakikulit boks.

\section{Penyerapan air}

Jumlah pigmen yang digunakan pada proses finishing berpengaruh pada penyerapan air selama 2 jam $(p<0,05)$, sedangkan tidak berpengaruh pada penyerapan air selama 24 jam $(p>0,05)$. Wakaso (2014) menyatakan bahwa pemberian pigmen menyebabkan kulit tahan terhadap absorpsi. Pendapat tersebut hanya berlaku pada penyerapan air selama 2 jam, sedangkan penyerapan air selama 24 jam diduga lebih dipengaruhi oleh binder dan resin. Perlakuan finishing menyebabkan air yang terserap ke dalam kulit lebih sedikit karena adanya lapisan dasar dan lapisan atas.

Hasil uji penyerapan air pada kulit sapi tersamak untuk semua perlakuan tampak seperti pada Gambar 2. Sampel yang menggunakan $15 \%$ pigmen menunjukkan persentase penyerapan air tertinggi, yaitu masing-masing 67,79\% (2 jam) dan 61,11\% (24 jam). Sampel dengan nilai penyerapan air terendah adalah $10 \%$ pigmen $(54,11 \%)$ selama 2 jam dan $12,5 \%$ pigmen $(65,48 \%)$ selama 24 jam. Rerata hasil uji penyerapan air selama 2 jam adalah 59,06\% dan selama 24 jam adalah $73,02 \%$. Semua sampel yang digunakan pada penelitian ini menunjukkan persentase penyerapan air di atas kontrol $(30,66 \%)$. Semua sampel, termasuk kontrol, memenuhi persyaratan SNI 0234: 2009 kulit bagian atas alas kaki-kulit boks yang mensyaratkan penyerapan air selama 2 jam maksimum $80 \%$ dan 24 jam maksimum 100\% (BSN, 2009).

\section{Permeabilitas dan penyerapan uap air}

Berdasarkan hasil penelitian dapat diketahui bahwa pigmen tidak berpengaruh pada permeabilitas uap air $(p<0,05)$. Serupa halnya dengan penyerapan uap air, berdasarkan uji pengaruh diketahui bahwa pigmen yang digunakan pada pelapisan dasar tidak berpengaruh pada penyerapan uap air. Pigmen berkaitan erat dengan ketebalan kulit, sehingga semakin tinggi

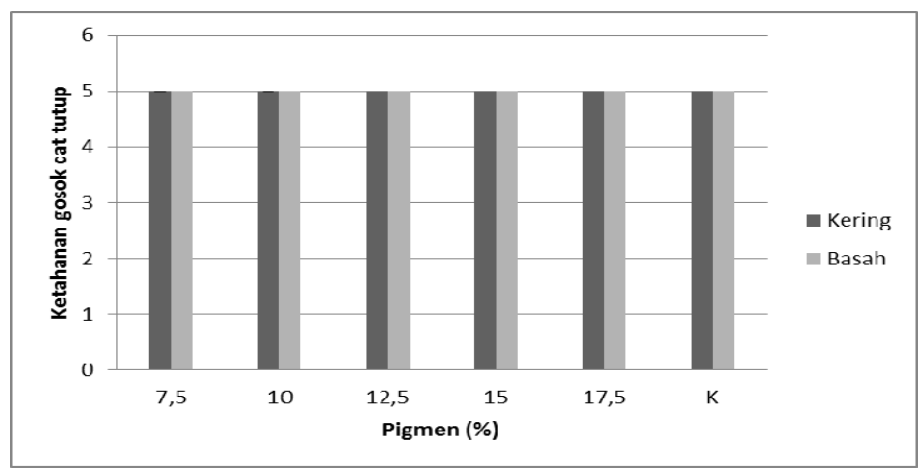

Gambar 1. Hasil uji ketahanan gosok cat tutup (kering dan basah) (rub fastness (dry and wet) test results). 


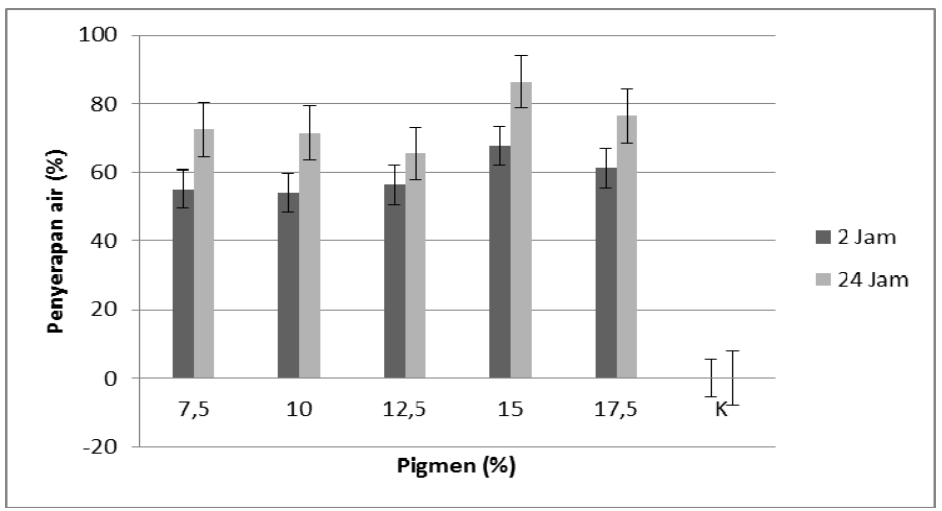

Gambar 2. Hasil uji penyerapan air (2 dan 24 jam) (water absorbtion test results).

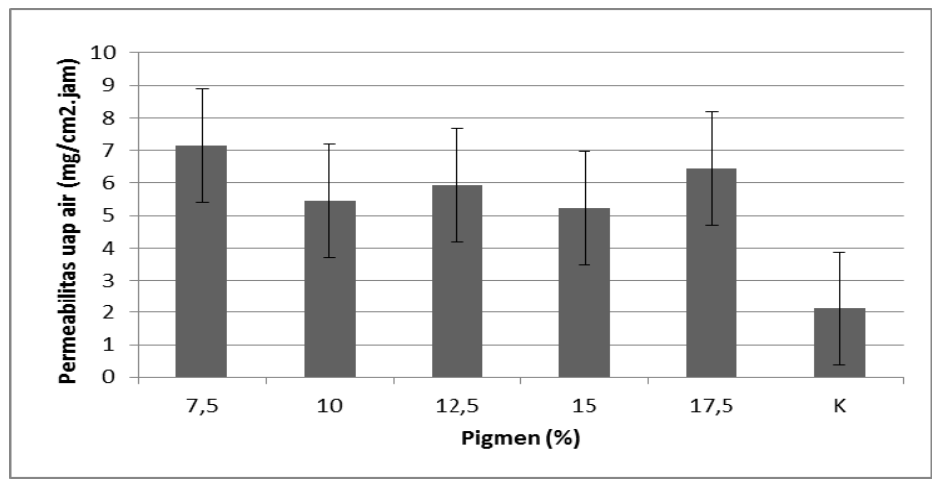

Gambar 3. Grafik hasil uji permeabilitas uap air (water vapour permeability test results).

ketebalan kulit maka kulit tersebut cenderung memiliki permeabilitas uap air yang rendah. Permeabilitas uap air merupakan proses yang meliputi beberapa tahapan, yaitu absorbsi, kelarutan, desorpsi, dan difusi (Jankauskaite et al., 2004). Pada penelitian diduga permeabilitas uap air dipengaruhi faktor selain pigmen, yaitu uretan resin yang digunakan pada lapisan dasar dan pemberian efek. Lebih lanjut, hal ini sesuai dengan pendapat Jankauskaite et al. (2004) bahwa uretan resin dapat memberikan permeabilitas uap air yang baik pada kulit. Guna menghasilkan sepatu yang nyaman, perpaduan antara permeabilitas uap air dan penyerapan uap air adalah hal yang penting karena permeabilitas uap air yang tinggi saja tidak cukup tanpa penyerapan yang baik karena penyerapan keringat dapat membantu kaki tetap kering (Kasmudjiastuti et al., 2016). Rendahnya nilai penyerapan uap air diduga karena lemahnya interaksi molekul air dengan kolagen yang ada dalam kulit serta kondensasi dan akumulasi uap air yang ada di sekitar lapisan adesif (Jankauskaite et al., 2004; Kasmudjiastuti et al., 2016).

Berdasarkan Gambar 3 permeabilitas uap air tertinggi adalah kulit yang formulasinya mengandung pigmen sebanyak $7,5 \% \quad\left(7,15 \quad \mathrm{mg} / \mathrm{cm}^{2}\right.$.jam $), \quad$ sedangkan terendah adalah kulit dengan pigmen sebanyak $15 \%\left(5,23 \mathrm{mg} / \mathrm{cm}^{2}\right.$.jam $)$. Sampel yang digunakan pada penelitian ini mempunyai nilai jauh diatas kontrol. Kulit dengan permeabilitas uap air yang tinggi menunjukkan bahwa sepatu dapat digunakan dengan nyaman karena permeabilitas uap air yang rendah dapat menyebabkan kaki menjadi basah dan bau karena terperangkapnya keringat (Kasmudjiastuti et al., 2016). Standar permeabilitas uap air berdasarkan ISO 20879: 2007 Footwear performance requirements for footwear-upper (ISO, 2007) adalah $\geq 0,8 \mathrm{mg} / \mathrm{cm}^{2}$.jam. Seluruh sampel yang digunakan memenuhi persyaratan tersebut. 


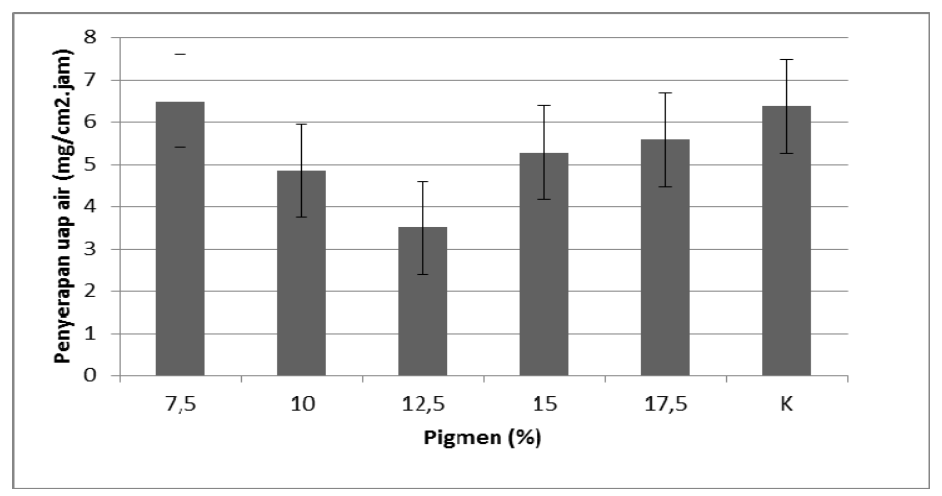

Gambar 4. Grafik hasil uji penyerapan uap air (water vapour absorption test results).

Nilai penyerapan uap air dapat dilihat pada Gambar 4 dengan nilai tertinggi adalah kulit yang diberi pigmen sebanyak 7,5\% $\left(6,49 \mathrm{mg} / \mathrm{cm}^{2}\right.$.jam $)$, sedangkan terendah adalah kulit dengan pigmen $12,5 \% \quad(3,50$ $\mathrm{mg} / \mathrm{cm}^{2} . j a m$ ). Seluruh sampel yang digunakan pada penelitian ini tidak memenuhi standar penyerapan uap air berdasarkan ISO 20879: 2007 footwear performance requirements for footwearupper (ISO, 2007), yaitu $\geq 8 \mathrm{mg} / \mathrm{cm}^{2}$.jam.

\section{Ketebalan lapisan finishing}

Ketebalan lapisan finishing, baik lapisan dasar maupun lapisan atas, diukur dengan menggunakan Scanning Electron Microscopy (SEM). Ketebalan diketahui dengan mengukur ketebalan di dua titik yang berbeda lalu dihitung nilai reratanya. Hasil analisa data menunjukkan bahwa pigmen berpengaruh pada ketebalan laipsan finishing dengan $p<0,05$.

Gambar 5 menunjukkan ketebalan laipsan finishing. Berdasarkan gambar tersebut dapat diketahui bahwa rerata ketebalan pada penelitian ini adalah 84,69 $\mu \mathrm{m}$. Lapisan yang paling tebal adalah yang menggunakan pigmen sebanyak $17,5 \%$ (140 $\mu \mathrm{m})$. Semakin banyak pigmen yang digunakan maka semakin tebal lapisan finishing yang dihasilkan (Gambar 6). Berdasarkan Gambar 6 uji SEM juga menunjukkan bahwa bahan kimia yang digunakan pada proses finishing dapat melekat baik dengan kulit. Campuran binder dan pigmen dapat membantu perekatan serta memberikan kelemasan dan kelenturan pada kulit, salah satunya adalah binder akrilik yang memiliki daya rekat baik (Hoefler et al., 2013; Kasmudjiastuti et al., 2016).
Pada Gambar 7 dapat diketahui bahwa semakin tinggi ketebalan lapisan finishing yang digunakan memiliki kecenderungan meningkatkan permeabilitas uap air. Hal ini bertentangan dengan hasil penelitian Smiechowski et al. (2014) yang menyatakan bahwa semakin tinggi lapisan yang dibuat maka semakin rendah permeabilitas uap air kulit tersebut. Salah satu tahapan dalam proses finishing adalah dengan proses tipping, yaitu memberikan efek pada kulit dengan menggunakan spons dan menempelkannya ke kulit (Tabel 3). Proses ini erat kaitannya dengan rasa dan seni, sehingga biasanya dilakukan oleh orang yang ahli dan memiliki rasa yang baik pada kulit. Ketebalan pada satu bagian dan bagian lainnya pada kulit dapat tidak sama dan tidak rata. Penyerapan uap air dan ketebalan lapisan finishing kulit mempunyai hubungan yang cenderung linier, yaitu semakin tebal lapisan finishing kulit maka penyerapan uap air kulit tersebut cenderung naik.

\section{Ketebalan kulit}

Setelah dilakukan analisa data, diperoleh hasil bahwa pigmen tidak berpengaruh pada ketebalan kulit $(p>0,05)$. Hal ini Ketebalan kulit hasil penelitian ini memiliki nilai rerata $1,052 \mathrm{~mm}$. Nilai tersebut cenderung sama dengan ketebalan kulit kontrol $(1,1 \mathrm{~mm})$. Berdasarkan Gambar 9 dapat diketahui bahwa seluruh kulit hasil penelitian memenuhi standar SNI 0234: 2009 kulit bagian atas alas kaki-kulit boks minimal 0,8 mm (BSN, 2009).

Faktor lain yang mempengaruhi permeabilitas uap air selain kandungan lemak dan kelembaban relatif, adalah 


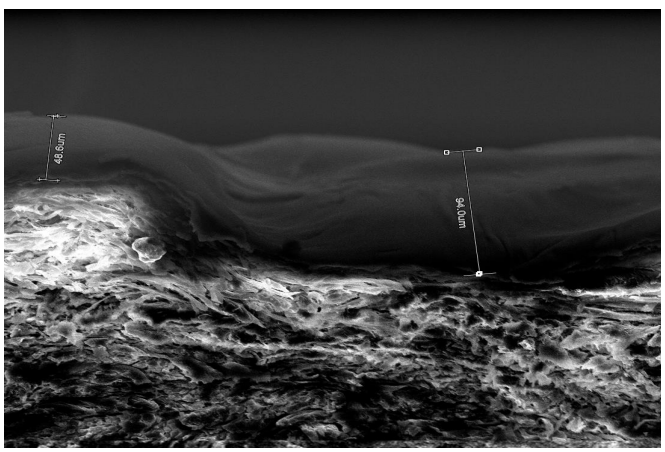

A

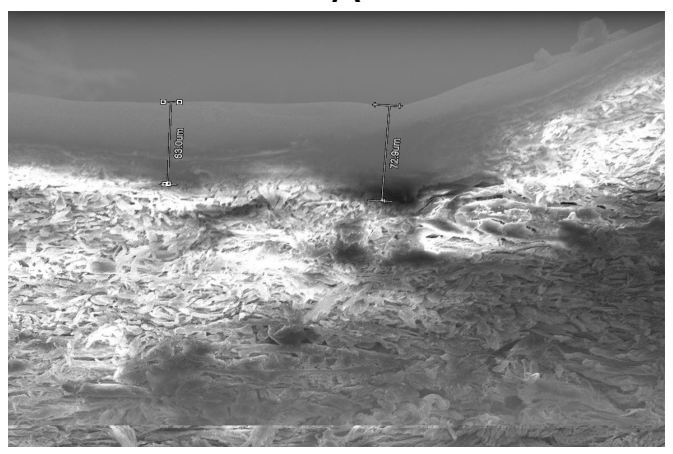

C

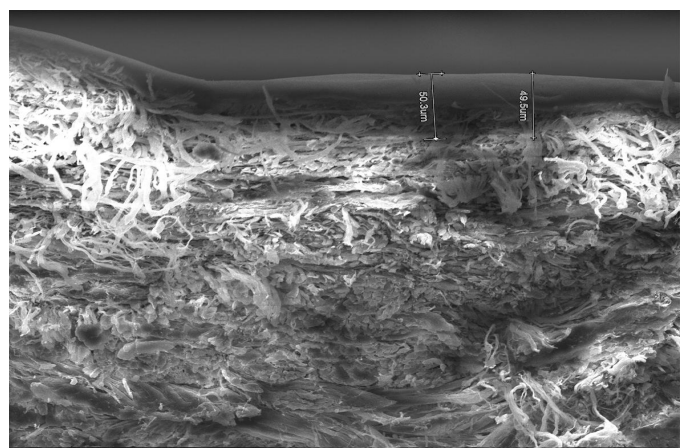

B

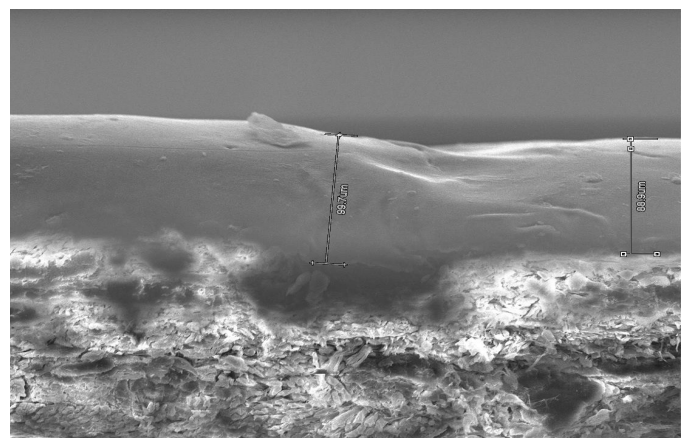

D

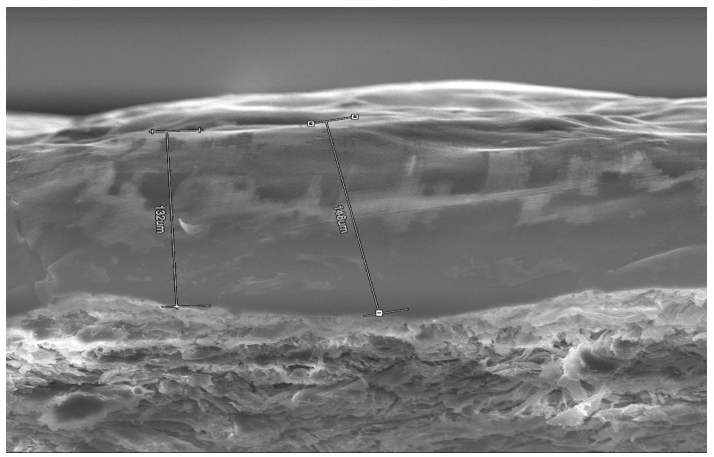

E

Gambar 5. Ketebalan lapisan finishing kulit dengan: A. 7,5\% pigmen; B. 10\% pigmen; C. 12,5\% pigmen; D. $15 \%$ pigmen; E. $17,5 \%$ pigmen

(leather coating thickness with A. $7,5 \%$ of pigment; B. $10 \%$ of pigment; C. $12,5 \%$ of pigment; D. $15 \%$ of pigment; E. $17,5 \%$ of pigment).

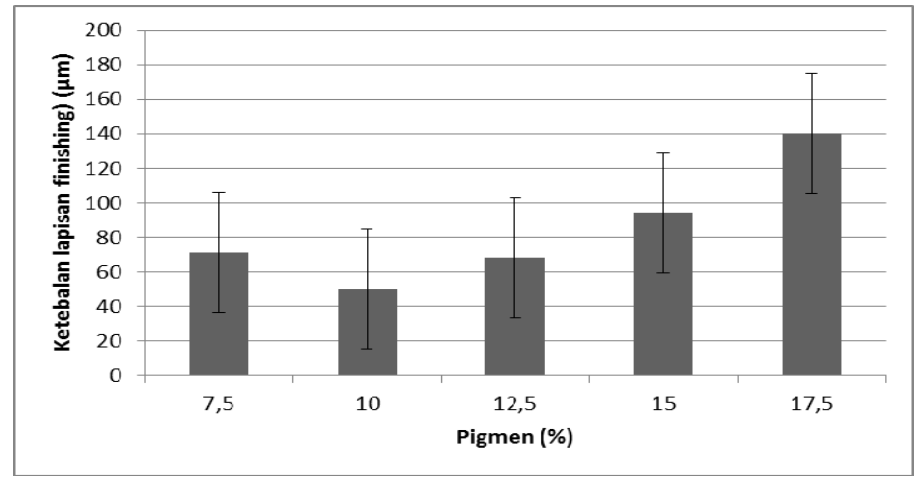

Gambar 6. Grafik ketebalan lapisan finishing kulit (leather coat thickness results). 


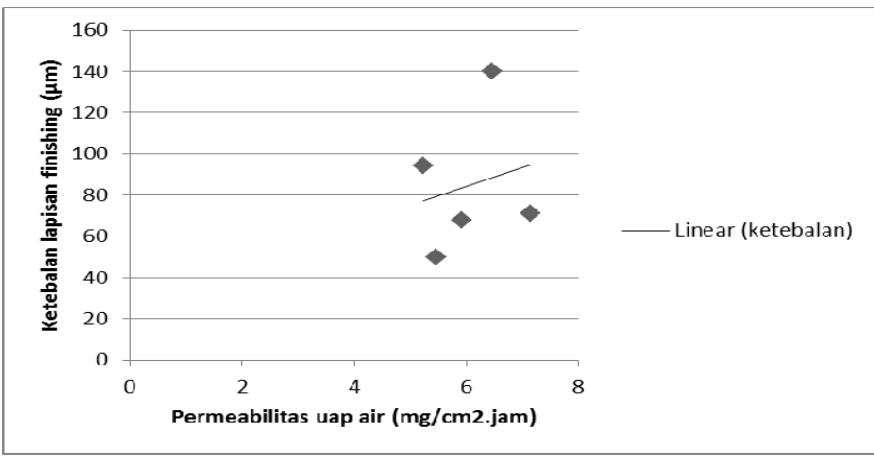

Gambar 7. Hubungan ketebalan lapisan finishing dengan permeabilitas uap air (the relationship between leather coat thickness with water vapour permeability).

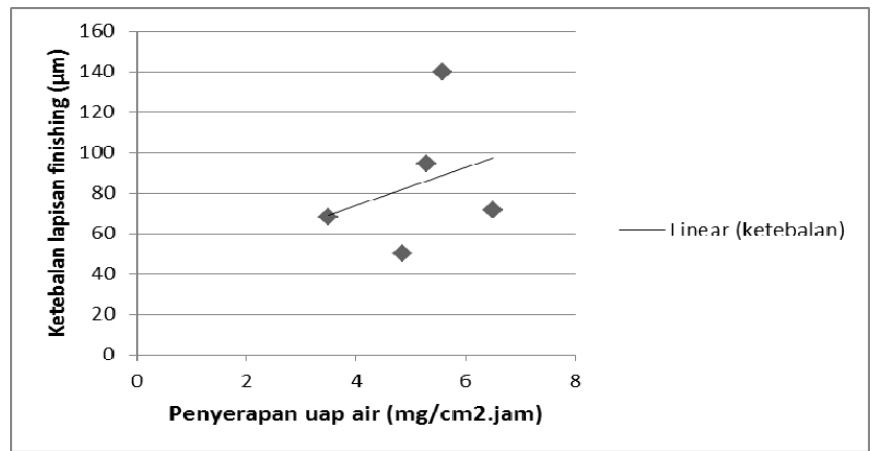

Gambar 8. Hubungan ketebalan lapisan finishing dengan penyerapan uap air (the relationship between leather coat thickness with water vapour absorption).

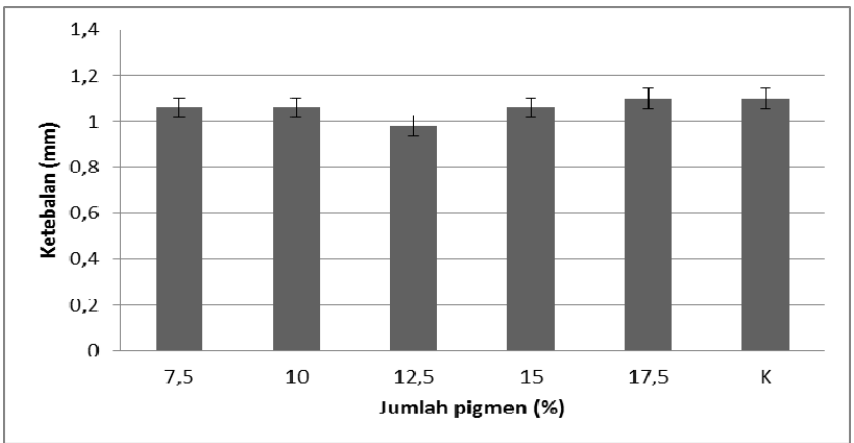

Gambar 9. Grafik ketebalan kulit (leather thickness results).

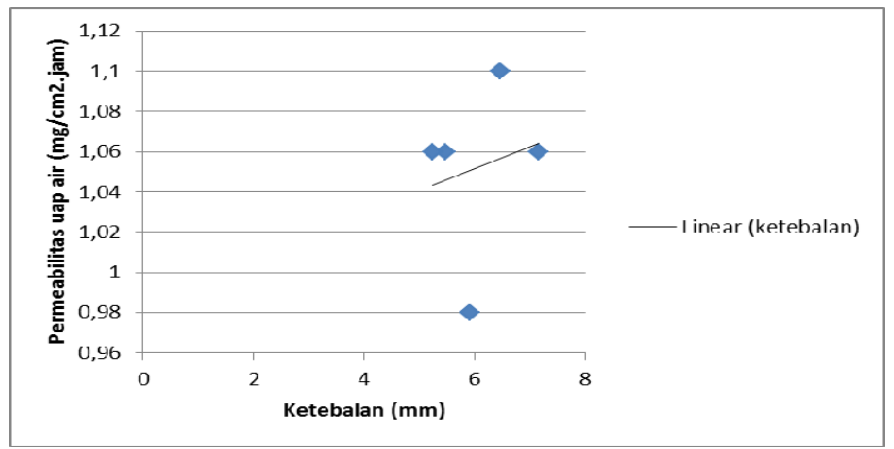

Gambar 10. Hubungan ketebalan kulit dengan permeabilitas uap air (the relationship between leather thickness with water vapour permeability). 


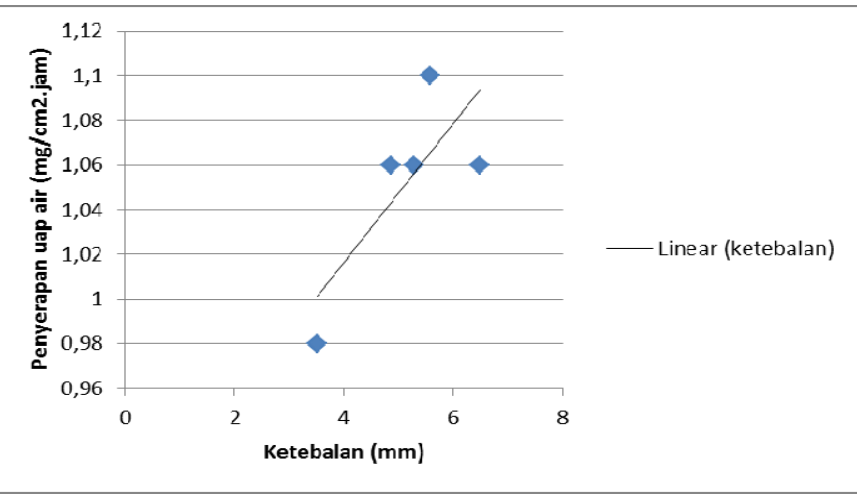

Gambar 11. Hubungan ketebalan kulit dengan penyerapan uap air (the relationship between leather thickness with water vapour absorption).

ketebalan kulit (Bekele, 2014). Hubungan ketebalan kulit dengan permeabilitas uap air pada penelitian dapat dilihat pada Gambar 10, sedangkan hubungan ketebalan kulit dengan penyerapan uap air pada Gambar 11. Berdasarkan gambar tersebut dapat diketahui bahwa semakin tinggi ketebalan kulit memiliki kecenderungan semakin tinggi permeabilitas uap airnya. Hal tersebut bertentangan dengan hasil penelitian Smiechowski et al. (2014) yang menyatakan bahwa semakin tinggi ketebalan maka semakin rendah permeabilitas kulit tersebut. Selain karena proses tipping yang berkaitan erat dengan teknisi yang melakukan, hal ini dapat juga disebabkan oleh bahan kimia yang digunakan pada proses finishing.

\section{Kesimpulan}

Hasil uji yang terkait dengan proses finishing menunjukkan bahwa penambahan jumlah pigmen pada pemberian lapisan dasar berpengaruh pada penyerapan air selama dua jam dan ketebalan lapisan finishing. Diduga faktor lain yang memengaruhi penyerapan air selama 24 jam, penyerapan uap air, dan penyerapan air adalah resin dan binder dengan formulasi yang tepat. Pigmen yang digunakan dalam formulasi penelitian dapat menghasilkan kulit yang memenuhi standar SNI 0234: 2009 kulit bagian atas alas kaki-kulit boks dan ISO 20879: 2007 footwear performance requirements for footwear-upper dari segi ketahanan gosok cat (kering dan basah) yang bernilai masing-masing 5 , penyerapan air (2 dan 24 jam) yaitu masing-masing $55,11 \%$ dan $72,49 \%$, dan permeabilitas uap air sebesar $7,15 \mathrm{mg} / \mathrm{cm}^{2}$.jam. Semakin tinggi ketebalan lapisan finishing maka permeabilitas uap air dan penyerapan uap air cenderung naik. Semakin tinggi ketebalan kulit maka permeabilitas uap air dan penyerapan uap air juga cenderung meningkat.

\section{Ucapan Terima Kasih}

Terimakasih kami ucapkan pada staf Laboratorium Finishing Kulit Balai Besar Kulit, Karet, dan Plastik, yang telah membantu terlaksananya penelitian ini.

\section{Daftar Pustaka}

Aravindhan, R., B. Madhan, P. Thanikaivelan, S. V. Kanth, J. R. Rao, C. S. Gnanasekaran, and B. U. Nair. 2008. Upgradation of leathers: Masking defects using pigments in pre-finishing processes. J. Scientific Industrial Research. 67: 233-238.

Bekele, M. 2014. Approach Towards High Performance Water Vapour Permeability Upper Leather from Goat Skin. Addis Ababa Institute of Technology, Addis Ababa.

BSN (Badan Standardisasi Nasional). 2009. Standard Nasional Indonesia SNI 0234: 2009 Kulit bagian atas alas kaki - kulit boks. BSN, Jakarta.

Covington, A. D. 2009. Tanning Chemistry: The Science of Leather. Royal Society of Chemistry, Cambridge.

Fantová, M., L. Nohejlová, and L. Stádník. 2015. Mechanical quality of leather in Texel lambs and their crossbreds. J. Central European Agriculture. 16: 5461. http://doi.org/10.5513/JCEA01/16.2.158 8.

Hoefler, J., B. Hageman, C. J. Chung, and R. Smith. 2013. High performance acrylic 
polymer technology for use in the leather finishing process. J. American Leather Chemists Association, 108: 311-317.

ISO (International Organization for Standardization). 2012a. ISO 14268: 2012: Leather - Physical and mechanical tests - Determination of water vapour permeability. ISO: Jenewa.

ISO (International Organization for Standardization). 2012b. ISO 20433: 2012 (en): Leather - Tests for colour fastness - Colour fastness to crocking. ISO: Jenewa.

ISO (International Organization for Standardization). 2016. ISO 17229: 2016: Leather - Physical and mechanical test - Determination of water vapour absorption. ISO: Jenewa.

ISO (International Organization for Standardizaton). $2011 . \quad$ ISO 20344:2011: Specifies methods for testing footwear designed as personal protective equipment. ISO: Jenewa.

ISO (International Standard Organization). 2007. ISO 20879:2007 Footwear performance requirements for footwearupper. ISO: Jenewa.

Jankauskaite, V. A. Gulbiniene, and K. V. Mickus. 2004. Effect of leather finishing technology on water vapour transmission. Part II. Water Vapour Transfer through Microporous Film Laminated Leather, 10: 249-254.

Kahsay, T., G. Negash, Y. Hagos, and B. Hadush. 2015. Pre-slaughter, slaughter and post-slaughter defects of skins and hides at the Sheba Tannery and Leather Industry, Tigray region, northern Ethiopia. Onderstepoort Veterinary Institute Onderstepoort South Africa, 82: 1-7. http://dx.doi.org/10.4102/OVJR.V82I1.9 31.

Kasmudjiastuti, E., B. Pidhatika, dan G. Griyanitasari. 2016. Pengaruh perbedaan jumlah penambahan binder uretan dan berbagai motif embossing terhadap kualitas kulit reject. Majalah Kulit, Karet, dan Plastik. 32: 39-50.

Olle, L., J. Bou, A. Shendrik, and A. Bacardit, 2014. Sustainable solvent-free finishing of patent leather using carbonylfunctional resins. J. Cleaner Production, 65: 590-594. http://doi.org/10.1016/j.jclepro.2013.07.
058.

Smiechowski, K., J. Zarlok, and M. Kowalska. 2014. The relationship between water vapour permeability and softness for leathers produced in poland. J. Society of Leather Technologist \& Chemist, 98: 259-263.

Sumarni, S. dan S. Triatmojo. 2013. Pengaruh penggunaan binder alami pada proses finishing kulit cakar ayam tersamak terhadap kekuatan sobek dan ketahanan gosok cat. Buletin Peternakan 37: 41-48.

Sundar, S., N. Vijayalakshmi, S. Gupta, R. Rajaram, and G. Radhakrishnan. 2006. Aqueous dispersions of polyurethanepolyvinyl pyridine cationomers and their application as binder in base coat for leather finishing. Progress in Organic Coatings, $\quad 56$ : 178-184. http://doi.org/10.1016/j.porgcoat.2006.0 4.001

Wakaso, M. 2014. Studies on Effect of Different Pigment and Binder Combinations on Surface Property of Finished Leather. PhD Proposal. Addis Ababa Institute of Technology: Addis Ababa.

Wu, Y., A. H. Wang, R. R. Zheng, H. Q. Tang, X. Y. Qi, and B. Ye. 2014. Laserdrilled micro-hole arrays on polyurethane synthetic leather for improvement of water vapor permeability. Applied Surface Science, 305: 1-8.

Xu, H., H. Ning, Y. Chen, H. Fan, and B. Shi. 2013. Sulfanilamide-conjugated polyurethane coating with enzymatically-switchable antimicrobial capability for leather finishing. Progress in Organic Coatings. 76: 924-934. http://doi.org/10.1016/j.porgcoat.2013.0 2.013

Yilmaz, O., C. N. Cheaburu, G. Gülümser, and C. Vasile. 2011. Rheological behaviour of acrylate/montmorillonite nanocomposite latexes and their application in leather finishing as binders. Progress in Organic Coatings, 70: $\quad$ 52-58. http://doi.org/10.1016/j. porgcoat.2010.10.001. 